\title{
Effect of supplementation of rumen protected choline and methionine on milk yield and composition of early lactating dairy cows
}

\author{
Neelima Jayaraj ${ }^{1}$, Sajith Purushothaman ${ }^{2}$, K. Ally ${ }^{3}$, \\ Deepa Ananth ${ }^{2}$ and Shibu Simon ${ }^{4}$ \\ Department of Animal Nutrition, College of Veterinary and Animal Sciences, \\ Mannuthy- 680651, Thrissur, Kerala \\ Kerala Veterinary and Animal Sciences University, India
}

Citation: Neelima, J., Sajith, P., Ally, K., Deepa, A. and Shibu, S. 2021. Effect of supplementation of rumen protected choline and methionine on milk yield and composition of early lactating dairy cows. J. Vet. Anim. Sci. 52(2): 142-148. DOI: https://doi.org/10.51966/jvas.2021.52.2.142-148

Received : 22.12.2020

Accepted: 01.02.2021

Published: 01.06.2021

\section{Abstract}

An experiment was conducted on early lactating dairy cows to study the effect of rumen protected choline (RPC) and methionine (RPM) on milk yield and composition. Fifteen crossbred dairy cows in early lactation (within 10 days of calving) were selected and randomly allotted to any one of the following three dietary treatments, $T_{1}$ (Control)- with compound feed mixture containing CP- $20 \%$ and TDN- 68\%, T2- $T_{1}+20 \mathrm{~g}$ RPM and $20 \mathrm{~g} \mathrm{RPC}$, T3- with compound fed mixture containing CP-17\%, TDN-68\% $+20 \mathrm{~g}$ RPM and $20 \mathrm{~g}$ RPC. All the experimental animals were fed as per ICAR feeding standards (ICAR, 2013). Results revealed no significant difference ( $p>0.05)$ in milk yield and 4 per cent fat corrected milk (FCM) yield between the three treatment groups. Among the milk constituents, animals in $T_{3}$ had significantly higher milk fat $(p<0.05), S N F(p<0.05)$, protein $(p<0.05)$ and total solids $(p<0.01)$ compared to those in $T 1$ and $T_{2}$. Milk urea nitrogen levels did not differ significantly among the three treatments and were within the normal range. The study showed that milk composition could be effectively improved by supplementing feed with rumen protected forms of choline and methionine in combination at lower dietary protein level without any reduction in milk yield.

Key words: Rumen protected choline, rumen protected methionine, early lactating dairy cows

India has ranked first among the world's milk producing nations since 1998 and the nation also has the largest bovine population in the World. Milk production in India during the period 195051 to 2018-19, increased from 17 million tonnes to 187.7 million tonnes (DAHD, 2020). The per

${ }^{\star}$ Part of MVSc thesis submitted to Kerala Veterinary and Animal Sciences University, Pookode, Wayanad, Kerala

1. MVSc Scholar and corresponding author: email-neelimajayaraj2208@gmail.com,

Ph: 9846687918

2. Assistant Professor

3. Professor and Head

4. Assistant Professor, Department of Animal Reproduction Gynaecology and Obstetrics

Copyright: () 2021 Neelima Jayaraj et al. This is an open access article distributed under the terms of the Creative Commons Attribution 4.0 International License (http://creativecommons.org/licenses/by/4.0/), which permits unrestricted use, distribution, and reproduction in any medium, provided the original author and source are credited. 
capita availability of milk in the country which was $130 \mathrm{~g} / \mathrm{d}$ during 1950-51 also increased to 394g/d in 2018-19 (NDDB, Anand). Data sheds light on sustained growth in the availability of milk and milk products for India's growing population.

During early lactation, the daily nutrient intake in cows is low and insufficient to meet the demands of milk production and the animal will be in negative energy balance. The amount of energy required for maintenance of body tissues and milk production often exceeds the amount of energy available from the diet, thus forcing mobilization of body fat reserves to satisfy energy requirement. The negative energy balance in early lactation affects peak milk yield and overall lactation yield. The level of non-esterified fatty acids (NEFA) increases in plasma as a consequence of body fat mobilization leading to hepatic lipidosis (Garg et al., 2012).

Choline, a component of phospholipid and methyl donor plays an important role in very low density lipoprotein synthesis and thereby contributes to fat export from the liver. Fat metabolism can be improved with the help of choline for better energy production. This also helps in improving milk production. Evidence suggests that the dietary supply of choline in early lactating dairy animals may be inadequate, even though choline can be synthesized by the animals (Pires and Grummer, 2008). As dietary choline gets degraded rapidly in the rumen, it must be supplemented in the protected form (Elek et al., 2008). Therefore, rumen protected form of choline has been developed to deliver choline to the small intestine for effective absorption.

Methionine is an essential amino acid and building block for protein and is considered as one of the two most limiting amino acids for milk production and milk protein synthesis in lactating dairy cows. Six per cent of the available choline in the body is derived from methionine and 28 per cent of the body's methionine is used for choline synthesis. Hence, the use of protected choline in the ration would help to spare the methionine, that could be used for milk production.

\section{Materials and methods}

\section{Location of study}

This study was conducted at the experimental animal shed of the University Livestock Farm \& Fodder Research and Development Scheme (ULF\&FRDS), College of Veterinary and Animal Sciences, Kerala, India.

\section{Experimental Animals, Feeding and Management}

Fifteen crossbred dairy cows in early lactation (within ten days of calving) were selected from University Livestock Farm and Fodder Research and Development Scheme, Mannuthy. They were divided into three groups of five animals each based on milk production and were randomly allotted to the three dietary treatments viz., T1, T2 or T3. The experimental animals, individually identified by numbered ear tags, were individually tethered with nylon ropes in a well- ventilated stall with uniform management practices and facilities for individual feeding throughout the experimental period of 90 days. Antiseptic solution was sprayed at regular intervals on the floor of the shed to ensure maximum hygiene. All the experimental animals were fed according to ICAR, 2013 guidelines with compound feed mixture (CFM) in mash form depending on the treatment group as follows; T1 (Control) - CFM containing crude protein (CP) - 20 per cent, total digestible nutrients (TDN) - 68 per cent, $\mathrm{T}_{2}-\mathrm{T}_{1}+20 \mathrm{~g}$ rumen protected methionine (metiPEARL; , Kemin Industries Pvt. Ltd.) and $20 \mathrm{~g}$ rumen protected choline (choliPEARL; Kemin industries Pvt. Ltd.) and T3- CFM containing CP- 17 per cent, TDN- 68 per cent+ $20 \mathrm{~g} \mathrm{RPM}$ and $20 \mathrm{~g}$ RPC. Supplements were mixed with CFM thoroughly, to ensure complete intake. All supplemental products used in the study were procured from local markets.

The roughage used to feed the animals was hybrid napier. Clean fresh drinking water was offered to all the animals ad libitum. Ingredient compositions of compound feed mixture used for the three treatments groups of experimental animals are given in Table 1. 
Table 1. Composition of compound feed mixture used in the three treatment groups

\begin{tabular}{|c|c|c|c|}
\hline \multirow{2}{*}{ Ingredient } & \multicolumn{3}{|c|}{ Percentage composition of compound feed mixture } \\
\hline & T1 & T2 & T3 \\
\hline Maize & 29.0 & 29.0 & 29.0 \\
\hline Rice polish & 6.0 & 6.0 & 13.0 \\
\hline Deoiled rice bran & 18.0 & 18.0 & 16.0 \\
\hline Corn gluten fibre & 17.5 & 17.5 & 15.5 \\
\hline Coconut cake & 10.5 & 10.5 & 15.5 \\
\hline Alfalfa & 16.0 & 16.0 & 8.0 \\
\hline Calcite & 1.5 & 1.5 & 1.5 \\
\hline Salt & 0.5 & 0.5 & 0.5 \\
\hline Mineral mixture & 1.0 & 1.0 & 1.0 \\
\hline Total & 100.0 & 100.0 & 100.0 \\
\hline Rumen protected methionine (g) & - & 20.0 & 20.0 \\
\hline Rumen protected choline (g) & - & 20.0 & 20.0 \\
\hline
\end{tabular}

Table 2. Chemical composition ${ }^{1}$ of the rations fed to experimental lactating cows ( \%)

\begin{tabular}{|l|c|c|c|c|}
\hline \multirow{2}{*}{ Parameter } & \multicolumn{3}{c|}{ Dietary treatments } & \\
\cline { 2 - 5 } & $T_{1}$ & $T_{2}$ & $T_{3}$ & Green grass \\
\hline Dry matter & $90.31 \pm 0.61$ & $90.31 \pm 0.61$ & $90.53 \pm 0.49$ & $15.00 \pm 0.33$ \\
\hline Crude protein & $20.93 \pm 0.14$ & $20.93 \pm 0.14$ & $17.06 \pm 0.58$ & $10.58 \pm 0.50$ \\
\hline Ether extract & $3.03 \pm 0.13$ & $3.03 \pm 0.13$ & $3.29 \pm 0.09$ & $2.17 \pm 0.20$ \\
\hline Crude fibre & $7.62 \pm 0.24$ & $7.62 \pm 0.24$ & $7.15 \pm 0.32$ & $29.83 \pm 0.23$ \\
\hline Total ash & $10.58 \pm 0.42$ & $10.58 \pm 0.42$ & $10.62 \pm 0.28$ & $9.55 \pm 0.32$ \\
\hline Nitrogen free extract & $57.81 \pm 0.16$ & $57.81 \pm 0.16$ & $61.85 \pm 0.08$ & $47.86 \pm 0.47$ \\
\hline Acid insoluble ash & $1.71 \pm 0.16$ & $1.71 \pm 0.16$ & $1.90 \pm 0.02$ & $1.36 \pm 0.23$ \\
\hline Calcium & $0.88 \pm 0.12$ & $0.88 \pm 0.12$ & $0.88 \pm 0.10$ & $0.52 \pm 0.07$ \\
\hline Phosphorus & $0.53 \pm 0.13$ & $0.53 \pm 0.13$ & $0.53 \pm 0.13$ & $0.23 \pm 0.06$ \\
\hline Neutral detergent fibre (NDF) & $52.86 \pm 0.36$ & $52.86 \pm 0.36$ & $47.15 \pm 0.25$ & $64.84 \pm 0.16$ \\
\hline Acid detergent fibre (ADF) & $14.39 \pm 0.15$ & $14.39 \pm 0.15$ & $16.74 \pm 0.04$ & $43.06 \pm 0.07$ \\
\hline
\end{tabular}

${ }^{1}$ Values expressed on DM basis, average of six values

The animals were milked twice a day, at 5 A.M. in the morning and at 2 P.M. in the afternoon. The data on milk yield recorded was used to calculate the daily milk yield for each animal throughout the experimental period. Morning and evening milk samples were collected from individual animals every fortnight and pooled samples were analysed for milk composition.

\section{Milk Analysis}

The collected milk samples were pooled and analysed for total solids, protein (AOAC, 2016) and fat (IS: 1224, 1977). From the above data, the solids not fat (SNF) was calculated. The milk urea nitrogen (Bector et al., 1998) was also analysed. 
Table 3. Fortnightly average milk production ${ }^{1}$ of lactating cows maintained on three experimental rations

\begin{tabular}{|c|c|c|c|c|}
\hline \multirow{2}{*}{ Fortnight } & \multicolumn{3}{|c|}{ Daily milk production (kg) } & \multirow{2}{*}{ p-value } \\
\hline & T1 & T2 & T3 & \\
\hline 1 & $12.23 \pm 1.53$ & $12.63 \pm 1.04$ & $10.57 \pm 1.16$ & $0.49^{\mathrm{ns}}$ \\
\hline 2 & $12.71 \pm 1.29$ & $12.71 \pm 1.39$ & $11.23 \pm 1.22$ & $0.66^{\mathrm{ns}}$ \\
\hline 3 & $12.58 \pm 1.02$ & $12.33 \pm 1.43$ & $11.41 \pm 1.14$ & $0.78^{\mathrm{ns}}$ \\
\hline 4 & $11.91 \pm 1.02$ & $12.25 \pm 1.37$ & $10.94 \pm 1.03$ & $0.71^{\mathrm{nS}}$ \\
\hline 5 & $11.92 \pm 0.92$ & $12.11 \pm 1.36$ & $10.97 \pm 1.02$ & $0.75^{\mathrm{ns}}$ \\
\hline 6 & $11.98 \pm 0.95$ & $11.76 \pm 1.31$ & $10.80 \pm 1.06$ & $0.74^{\mathrm{ns}}$ \\
\hline Mean \pm S.E. & $12.22 \pm 1.12$ & $12.29 \pm 1.31$ & $10.98 \pm 1.10$ & $0.55^{\mathrm{ns}}$ \\
\hline
\end{tabular}

${ }^{1}$ Mean values are based on five replicates with S.E.; ns- non significant

Table 4. Fortnightly average 4 per cent FCM yield of lactating cows maintained on three experimental rations

\begin{tabular}{|c|c|c|c|c|}
\hline \multirow{2}{*}{ Fortnight } & \multicolumn{3}{|c|}{ Daily milk production (kg) } & \multirow{2}{*}{ p-value } \\
\cline { 2 - 4 } & T1 & T2 & T3 & \multirow{2}{*}{$0.67^{\mathrm{ns}}$} \\
\hline 1 & $11.30 \pm 1.34$ & $12.03 \pm 0.92$ & $10.57 \pm 1.10$ & $0.90^{\mathrm{ns}}$ \\
\hline 2 & $11.66 \pm 1.04$ & $11.99 \pm 1.26$ & $11.22 \pm 1.25$ & $0.87^{\mathrm{ns}}$ \\
\hline 3 & $11.51 \pm 0.80$ & $12.15 \pm 1.45$ & $11.31 \pm 1.14$ & $0.78^{\mathrm{ns}}$ \\
\hline 4 & $10.95 \pm 0.86$ & $11.86 \pm 1.26$ & $10.89 \pm 1.02$ & $0.90^{\mathrm{ns}}$ \\
\hline 5 & $11.19 \pm 0.87$ & $11.72 \pm 1.24$ & $11.08 \pm 0.95$ & $0.97^{\mathrm{ns}}$ \\
\hline 6 & $11.32 \pm 0.97$ & $11.33 \pm 1.22$ & $11.02 \pm 1.02$ & $0.74^{\mathrm{ns}}$ \\
\hline Mean \pm S.E. & $11.32 \pm 1.08$ & $11.89 \pm 1.11$ & $11.01 \pm 1.01$ & ${ }^{2}$ \\
\hline
\end{tabular}

${ }^{1}$ Mean values are based on five replicates with S.E.; ns- non significant

The experimental design used in the study was completely randomised design. Data obtained on various parameters were analysed statistically (Snedecor and Cochran, 1994) and the comparison of means was done using IBM Statistical Production and Service Solutions (SPSS), version 24.0.

\section{Results and Discussion}

The per cent chemical composition of the ration fed to experimental lactating cows is shown in Table 2.

\section{Milk production}

Consolidated data on fortnightly average milk production and fortnightly average 4 per cent FCM yield of the lactating cows maintained on three treatments $T_{1}, T_{2}$ and $T_{3}$ are given in Table 3 and 4, respectively. The average daily milk production of experimental lactating cows maintained on dietary treatments $\mathrm{T} 1, \mathrm{~T} 2$ and $\mathrm{T} 3$ were $12.22 \pm 1.12,12.29 \pm 1.31$ and $10.98 \pm 1.10 \mathrm{~kg}$, respectively. Statistical analysis of the data revealed that there was no significant difference in average daily milk production of lactating cows maintained on the three dietary treatments. Tamura et al. (2018) observed that early lactating dairy cattle supplemented with 8g/day RPM top dressed on the TMR having 14.5per cent C.P did not have any significant effect on milk yield and both the groups had a milk production of around $40 \mathrm{~kg} /$ day. Similarly, Pawar et al. (2015) reported no significant difference in milk yield of crossbred lactating cows supplemented with $54 \mathrm{~g} /$ head/day RPC $(16.93 \pm 1.57 \mathrm{~kg} /$ day) mixed with the basal ration when compared with the control $(15.38 \pm 0.88$ $\mathrm{kg} /$ day). These results were in accordance with those of the present study. Milk yield and 4 per cent FCM yield were not significantly improved in the above studies which may be because the 
Table 5. Fortnightly average milk composition ${ }^{1}$ of lactating cows maintained on three experimental rations, $\mathbf{k g}$

\begin{tabular}{|c|c|c|c|c|c|c|c|c|}
\hline \multirow{2}{*}{ Parameter } & \multirow{2}{*}{ Treatment } & \multicolumn{6}{|c|}{ Fortnights } & \multirow{2}{*}{ Mean $\pm S}$. \\
\hline & & 1 & 2 & 3 & 4 & 5 & 6 & \\
\hline \multirow{3}{*}{ Fat (\%) } & $\mathrm{T}_{1}$ & $\begin{array}{l}3.52^{\mathrm{b}} \\
\pm 0.08\end{array}$ & $\begin{array}{l}3.49^{b} \\
\pm 0.11\end{array}$ & $\begin{array}{l}3.47^{b} \\
\pm 0.13\end{array}$ & $\begin{array}{l}3.48^{b} \\
\pm 0.12\end{array}$ & $\begin{array}{l}3.60^{\mathrm{b}} \\
\pm 0.17\end{array}$ & $\begin{array}{l}3.63^{b} \\
\pm 0.20\end{array}$ & $\begin{array}{l}3.53^{b} \\
\pm 0.14\end{array}$ \\
\hline & $\mathrm{T}_{2}$ & $\begin{array}{l}3.71^{\mathrm{b}} \\
\pm 0.17\end{array}$ & $\begin{array}{l}3.65^{\mathrm{b}} \\
\pm 0.15\end{array}$ & $\begin{array}{l}3.91^{\mathrm{b}} \\
\pm 0.27\end{array}$ & $\begin{array}{l}3.81^{\mathrm{b}} \\
\pm 0.18\end{array}$ & $\begin{array}{l}3.80^{\mathrm{b}} \\
\pm 0.11\end{array}$ & $\begin{array}{l}3.77^{b} \\
\pm 0.08\end{array}$ & $\begin{array}{l}3.78^{b} \\
\pm 0.18\end{array}$ \\
\hline & $\mathrm{T}_{3}$ & $\begin{array}{l}4.01^{a} \\
\pm 0.16\end{array}$ & $\begin{array}{l}3.98^{a} \\
\pm 0.13\end{array}$ & $\begin{array}{l}3.94^{\mathrm{a}} \\
\pm 0.12\end{array}$ & $\begin{array}{l}3.97^{a} \\
\pm 0.12\end{array}$ & $\begin{array}{l}4.10^{\mathrm{a}} \\
\pm 0.17\end{array}$ & $\begin{array}{l}4.18^{a} \\
\pm 0.24\end{array}$ & $\begin{array}{l}4.03^{a} \\
\pm 0.15\end{array}$ \\
\hline \multirow{3}{*}{ SNF (\%) } & $\mathrm{T}_{1}$ & $\begin{array}{c}8.00 \\
\pm 0.10\end{array}$ & $\begin{array}{l}7.81^{\mathrm{b}} \\
\pm 0.07\end{array}$ & $\begin{array}{c}7.71 \\
\pm 0.02\end{array}$ & $\begin{array}{l}7.75^{\mathrm{b}} \\
\pm 0.06\end{array}$ & $\begin{array}{c}7.85 \\
\pm 0.06\end{array}$ & $\begin{array}{c}7.76 \\
\pm 0.11\end{array}$ & $\begin{array}{l}7.81^{\mathrm{b}} \\
\pm 0.07\end{array}$ \\
\hline & $\mathrm{T}_{2}$ & $\begin{array}{c}8.19 \\
\pm 0.18\end{array}$ & $\begin{array}{l}8.03^{a b} \\
\pm 0.09\end{array}$ & $\begin{array}{c}7.88 \\
\pm 0.21\end{array}$ & $\begin{array}{l}7.77^{\mathrm{ab}} \\
\pm 0.08\end{array}$ & $\begin{array}{c}7.78 \\
\pm 0.09\end{array}$ & $\begin{array}{c}7.69 \\
\pm 0.03\end{array}$ & $\begin{array}{l}7.89^{\mathrm{ab}} \\
\pm 0.12\end{array}$ \\
\hline & $\mathrm{T}_{3}$ & $\begin{array}{c}8.30 \\
\pm 0.09 \\
\end{array}$ & $\begin{array}{l}8.21^{a} \\
\pm 0.06\end{array}$ & $\begin{array}{c}8.06 \\
\pm 0.02 \\
\end{array}$ & $\begin{array}{l}7.96^{a} \\
\pm 0.02\end{array}$ & $\begin{array}{c}7.91 \\
\pm 0.03 \\
\end{array}$ & $\begin{array}{c}7.82 \\
\pm 0.04\end{array}$ & $\begin{array}{l}8.04^{a} \\
\pm 0.04\end{array}$ \\
\hline \multirow{3}{*}{$\begin{array}{c}\text { Total } \\
\text { solids (\%) }\end{array}$} & $\mathrm{T}_{1}$ & $\begin{array}{l}11.43^{\mathrm{b}} \\
\pm 0.05\end{array}$ & $\begin{array}{l}11.51^{\mathrm{b}} \\
\pm 0.03\end{array}$ & $\begin{array}{l}11.58^{b} \\
\pm 0.18\end{array}$ & $\begin{array}{l}11.46^{\mathrm{b}} \\
\pm 0.12\end{array}$ & $\begin{array}{l}11.55^{\mathrm{b}} \\
\pm 0.16\end{array}$ & $\begin{array}{l}11.54^{\mathrm{b}} \\
\pm 0.20\end{array}$ & $\begin{array}{l}11.51^{\mathrm{b}} \\
\pm 0.07\end{array}$ \\
\hline & $\mathrm{T}_{2}$ & $\begin{array}{l}11.68^{\mathrm{b}} \\
\pm 0.12 \\
\end{array}$ & $\begin{array}{l}11.79^{\mathrm{b}} \\
\pm 0.07\end{array}$ & $\begin{array}{l}11.68^{b} \\
\pm 0.15\end{array}$ & $\begin{array}{l}11.79^{b} \\
\pm 0.16\end{array}$ & $\begin{array}{l}11.59^{\mathrm{b}} \\
\pm 0.10\end{array}$ & $\begin{array}{l}11.60^{\mathrm{b}} \\
\pm 0.07\end{array}$ & $\begin{array}{l}11.68^{b} \\
\pm 0.12 \\
\end{array}$ \\
\hline & $\mathrm{T}_{3}$ & $\begin{array}{l}12.86^{a} \\
\pm 0.19 \\
\end{array}$ & $\begin{array}{l}12.71^{\mathrm{a}} \\
\pm 0.08\end{array}$ & $\begin{array}{l}12.46^{a} \\
\pm 0.09\end{array}$ & $\begin{array}{l}12.39^{a} \\
\pm 0.10\end{array}$ & $\begin{array}{l}12.37^{\mathrm{a}} \\
\pm 0.13\end{array}$ & $\begin{array}{l}12.43^{\mathrm{a}} \\
\pm 0.07\end{array}$ & $\begin{array}{l}12.54^{a} \\
\pm 0.10\end{array}$ \\
\hline \multirow{3}{*}{$\begin{array}{c}\text { Protein } \\
(\%)\end{array}$} & $\mathrm{T}_{1}$ & $\begin{array}{l}2.93^{\mathrm{b}} \\
\pm 0.04 \\
\end{array}$ & $\begin{array}{r}2.85 \\
\pm 0.03 \\
\end{array}$ & $\begin{array}{l}2.80^{\mathrm{b}} \\
\pm 0.02 \\
\end{array}$ & $\begin{array}{l}2.84^{b} \\
\pm 0.03 \\
\end{array}$ & $\begin{array}{c}2.83 \\
\pm 0.03 \\
\end{array}$ & $\begin{array}{c}2.83 \\
\pm 0.04\end{array}$ & $\begin{array}{l}2.85^{b} \\
\pm 0.04\end{array}$ \\
\hline & $\mathrm{T}_{2}$ & $\begin{array}{l}2.94^{b} \\
\pm 0.02\end{array}$ & $\begin{array}{c}2.89 \\
\pm 0.02\end{array}$ & $\begin{array}{l}2.84^{\mathrm{b}} \\
\pm 0.03\end{array}$ & $\begin{array}{l}2.86^{b} \\
\pm 0.01\end{array}$ & $\begin{array}{c}2.86 \\
\pm 0.02\end{array}$ & $\begin{array}{c}2.82 \\
\pm 0.01\end{array}$ & $\begin{array}{l}2.87^{b} \\
\pm 0.03\end{array}$ \\
\hline & $\mathrm{T}_{3}$ & $\begin{array}{l}3.04^{a} \\
\pm 0.03 \\
\end{array}$ & $\begin{array}{c}2.93 \\
\pm 0.05\end{array}$ & $\begin{array}{l}2.93^{a} \\
\pm 0.02 \\
\end{array}$ & $\begin{array}{l}2.92^{a} \\
\pm 0.02 \\
\end{array}$ & $\begin{array}{c}2.91 \\
\pm 0.02 \\
\end{array}$ & $\begin{array}{c}2.84 \\
\pm 0.03 \\
\end{array}$ & $\begin{array}{l}2.92^{a} \\
\pm 0.04\end{array}$ \\
\hline \multirow{3}{*}{$\begin{array}{c}\text { MUN } \\
(\mathrm{mg} / \mathrm{dL})\end{array}$} & $\mathrm{T}_{1}$ & $\begin{array}{l}13.63 \\
\pm 0.10\end{array}$ & $\begin{array}{l}13.74 \\
\pm 0.09\end{array}$ & $\begin{array}{l}13.82 \\
\pm 0.08\end{array}$ & $\begin{array}{l}14.06 \\
\pm 0.11\end{array}$ & $\begin{array}{l}14.15 \\
\pm 0.12\end{array}$ & $\begin{array}{l}14.31 \\
\pm 0.14\end{array}$ & $\begin{array}{l}13.95 \\
\pm 0.07\end{array}$ \\
\hline & $\mathrm{T}_{2}$ & $\begin{array}{l}13.11 \\
\pm 0.23\end{array}$ & $\begin{array}{l}13.23 \\
\pm 0.26\end{array}$ & $\begin{array}{l}13.30 \\
\pm 0.22\end{array}$ & $\begin{array}{l}13.54 \\
\pm 0.32\end{array}$ & $\begin{array}{l}13.63 \\
\pm 0.31\end{array}$ & $\begin{array}{l}13.78 \\
\pm 0.30\end{array}$ & $\begin{array}{l}13.43 \\
\pm 0.22\end{array}$ \\
\hline & $\mathrm{T}_{3}$ & $\begin{array}{l}11.98 \\
\pm 0.17\end{array}$ & $\begin{array}{l}12.09 \\
\pm 0.19\end{array}$ & $\begin{array}{l}12.17 \\
\pm 0.22\end{array}$ & $\begin{array}{l}12.41 \\
\pm 0.17\end{array}$ & $\begin{array}{l}12.50 \\
\pm 0.23\end{array}$ & $\begin{array}{l}12.65 \\
\pm 0.22\end{array}$ & $\begin{array}{r}12.30 \\
\pm 0.24\end{array}$ \\
\hline
\end{tabular}

a,b Values in the columns bearing different superscripts differ significantly $(p<0.05 / 0.01)$

animals selected for the experiment were only medium producers rather than high yielders.

\section{Milk composition}

Data on composition of milk collected fortnightly from the lactating cows maintained on the three experimental rations are shown in Table 5.

The average milk fat (\%) content in milk from animals fed on the three dietary treatments $\mathrm{T}_{1}, \mathrm{~T}_{2}$ and $\mathrm{T} 3$ were $3.53 \pm 0.14,3.78 \pm 0.18$ and
$4.03 \pm 0.15$ per cent, respectively. The per cent fat in milk was higher $(p<0.05 / 0.01)$ in $T_{3}$ when compared to $T_{1}$ and $T_{2}$. However, no significant differences ( $p>0.05)$ were observed between $\mathrm{T}_{1}$ and $\mathrm{T}_{2}$. Titi et al. (2013) conducted studies on Holstein heifers fed with TMR containing 14 or 16 per cent CP supplemented with 0,15 or 25 g/day RPM and they observed a significantly higher milk fat content in the group fed with the ration containing 14 per cent crude protein with $25 \mathrm{~g} /$ day RPM $(3.61 \pm 0.01$ per cent) compared with the non-supplemented group and the supplemented group with higher CP in ration 
and the values were $3.42 \pm 0.01$ per cent and $3.55 \pm 0.01$ per cent for the non-supplemented group and the supplemented group with higher $\mathrm{CP}$ in ration, respectively.

The improvement in milk fat content maybe due tothe role of methionine in increasing the de novo synthesis of both short and medium chain fatty acids in the mammary gland as well as choline, both of which are is essential for the synthesis of phospholipids that are inturn, required for the synthesis of chylomicrons and very low-density lipoproteins.

The average milk solids not fat (SNF) content of milk from animals maintained on the three dietary treatments $\mathrm{T}_{1}, \mathrm{~T}_{2}$ and $\mathrm{T}_{3}$ were $7.81 \pm 0.07,7.89 \pm 0.12$ and $8.04 \pm 0.04$ per cent, respectively. The SNF content (\%) of milk was higher $(p<0.05 / 0.01)$ in $T_{3}$ when compared to $T_{1}$, while no significant differences $(p>0.05)$ were observed between $T_{1}$ and $T_{2}$ and, $T_{2}$ and $T_{3}$ in this regard. Ahmed et al. (2016) observed that the supplementation of RPM@ 7g/day RPM in combination with $20 \mathrm{~g} /$ day RPL had significantly improved milk SNF content $(9.91 \pm 0.07$ per cent) when compared to the control $(9.51 \pm 0.16$ per cent) in early lactating Nili Ravi buffaloes. Similarly, Rahmani et al. (2014) concluded that feeding TMR top dressed with $90 \mathrm{~g} /$ day RPC to early lactating Holstein cows had significantly improved the SNF content of milk $(8.87 \pm 0.05 \mathrm{per}$ cent) when compared to the control $(8.67 \pm 0.04$ per cent). These results were in accordance with the results obtained in the present study.

The average milk total solids (\%) content of milk were $11.51 \pm 0.07,11.69 \pm 0.12$ and $12.54 \pm 0.10$ per cent in $T_{1}, T_{2}$ and $T_{3}$ groups, respectively. The average total solids $(\%)$ in milk was higher in $\mathrm{T}_{3}$ when compared to $T_{1}$ and $T_{2}$, while no significant difference ( $p>0.05$ ) was observed between $T_{1}$ and $T_{2}$ groups. The increase in milk total solids resulted from a combined increase in fat and protein concentration. Sheikh et al. (2014) reported a significantly higher milk total solids content (13.54 \pm 0.15 per cent) in Karan Fries lactating dairy cows on supplementation with rumen protected methionine and choline @7 and 60g/ day, respectively along with the basal ration when compared with the control $(12.92 \pm 0.08$ per cent).
The average milk protein content in milk was $2.85 \pm 0.04,2.87 \pm 0.03$ and $2.92 \pm 0.04$ per cent in $T_{1}, T_{2}$ and $T_{3}$ groups, respectively. The average milk protein content increased significantly $(p<0.05 / 0.01)$ in $\mathrm{T}_{3}$ when compared to $T_{1}$ and $T_{2}$, while no significant difference ( $p>0.05$ ) was observed between $T_{1}$ and $T_{2}$. These findings were in accordance with those made by Davidson et al. (2008), who observed a significantly higher milk protein content (2.77 \pm 0.06 per cent) in early lactating dairy cows upon supplementation with RPM and RPC @ 40 and $45 \mathrm{~g} /$ day, respectively top dressed on the TMR having 17.6 per cent $\mathrm{CP}$ when compared to the control $(2.60 \pm 0.06$ per cent). Choline is a source of methyl groups and it also acts as a methyl donor in transmethylation reactions which may be the reason for the improvement in the milk protein content in the supplemented groups.

The average milk urea nitrogen (MUN) ( $\mathrm{mg} / \mathrm{dL})$ content in milk from animals maintained on the three dietary treatments $\mathrm{T}_{1}, \mathrm{~T}_{2}$ and $\mathrm{T}_{3}$ were $13.95 \pm 0.07,13.43 \pm 0.22$ and $12.30 \pm 0.24$ $\mathrm{mg} / \mathrm{dL}$, respectively. Statistical analysis of the data revealed no significant difference $(p>0.05)$ in MUN content of the milk of lactating cows maintained on three different dietary treatments. The present observations were similar to those made by Zhou et al. (2016) in transition dairy cows where the authors reported that dairy cows supplemented with RPM $(0.08 \%$ DM of TMR) and $60 \mathrm{~g} /$ day RPC didn't show any significant difference $(12.82 \pm 0.40 \mathrm{mg} / \mathrm{dL})$ in milk urea nitrogen content when compared with the control $(12.65 \pm 0.40 \mathrm{mg} / \mathrm{dL})$.

\section{References}

Ahmed, S., Gohar, M., Khalique, A., Ahmad, N., Shahzad, F., Rahman, A. and Khan, M.I. 2016. Effect of supplementation of rumen protected lysine and methionine on production performance, milk and blood parameters of early lactating niliravi buffaloes. Pak. J. Zool. 48: 56-63.

AOAC. 2016. Official Methods of Analysis. (20 ${ }^{\text {th }}$ Ed.). Association of Official Analytical Chemists, Gaithersburg, Meryland, USA.

Bector, B.S., Ram, M. and Singhal, O.P. 1998. 
Rapid platform test for detection and determination of added urea in milk. Indian Dairyman, 50: 59- 62.

DAHD, 2020. Annual report 2019-2020. Available: https:/dahd.nic.in/sites/ default/filess/Annu al\%20Report.pdf [26 Nov. 2020]

Davidson, S., Hopkins, B.A., Odle, J., Brownie, C., Fellner, V. and Whitlow, L.W. 2008. Supplementing limited methionine diets with rumen-protected methionine, betaine and choline in early lactation Holstein cows. J. Dairy Sci. 91: 15521559.

Elek, P., Newbold, J.R., Gaal, T., Wagner,L. and Husveth, F. 2008. Effects of rumenprotected choline supplementation on milk production and choline supply of periparturient dairy cows. Int. J. Anim. Biosci. 2: 1595-1602.

Garg, M.R., Bhanderi, B.M. and Sherasia, P.L. 2012. Effect of supplementing bypass fat with rumen protected choline chloride on milk yield, milk composition and metabolic profile in crossbred cows. Indian J. Dairy Sci. 65: 319-323.

ICAR [Indian Council of Agricultural Research]. 2013. Nutrient requirement of Animalscattle and buffalo. (3rd Ed.). Indian Council of Agricultural Research, New Delhi, 59p.

IS: 1224. [Indian Standards Institution]. 1977. Determination of fat by Gerber's Method part 1. Milk (First Revision), Indian

Pawar, S.P., Kewalramani, N., Thakur, S.S. and Kaur, J. 2015. Effect of dietary rumen protected choline supplementation on milk choline content in crossbred cows. Ind. J. Anim. Nutr. 32: 30-35.
Pires, J. and Grummer, R. 2008. Micronutrients and their impact on high performing dairy cows-A focus on niacin and choline. Anim. Nutr. 5: 317-325.

Rahmani, M., Dehghan-Banadaky, M. and Kamalyan, R. 2014. Effects of feeding rumen protected choline and vitamin $\mathrm{E}$ on milk yield, milk composition, dry matter intake, body condition score and body weight in early lactating dairy cows. Iran.J. Appl. Anim. Sci. 4: 693-698.

Sheikh, F.A., Kewalramani, N., Thakur,S.S. and Mir, I.A. 2014. Effect of supplementation of rumen protected methionine-lysine and choline on milk production in crossbred cows. Ind. J. Anim. Nutr. 31: 148-151.

Snedecor, G.W. and Cochran, W.G. 1994. Statistical Methods. (8th Ed.). The lowa state university press, Ames, 503p.

Tamura, T., Inoue, K., Nishiki, H., Sakata, M., Seki, M., Koga, T., Ookubo, Y., Akutsu, K., Sato, S., Saitou, K. and Shinohara, H. 2018. Effects of rumen - protected methionine on milk production in early lactation dairy cattle fed with a diet containing $14.5 \%$ crude protein. Anim. Sci. J. 90: 62-70.

Titi, H.H., Azzam, S.I. and Alnimer, M.A. 2013. Effect of protected methionine supplementation on milk production and reproduction in first calf heifers. Arch. Tierzucht. 56: 225-236.

Zhou, Z., Vailati-Riboni, M., Trevisi, E., Drackley, J.K., Luchini, D.N. and Loor, J.J. 2016. Better postpartum performance in dairy cows supplemented with rumenprotected methionine compared with choline during the peripartal period. J. Dairy Sci. 99: 8716-8732. 